\title{
Hepatitis E vaccines - Current scenario
}

\author{
Kamran Zaman ${ }^{1}$, Kapil Goyal ${ }^{2}$ and Mini P Singh ${ }^{3 *}$ \\ ${ }^{1}$ Department of Medical Microbiology, Postgraduate Institute of Medical Education and Research, Chandigarh, India \\ ${ }^{2}$ Department of Medical Parasitology, Postgraduate Institute of Medical Education and Research, Chandigarh, India \\ ${ }^{3}$ Department of Virology, Postgraduate Institute of Medical Education and Research, Chandigarh, India
}

\section{Introduction}

Hepatitis $\mathrm{E}$ is an important global public health disease with worldwide annual estimate of 20 million new infections, of which around 3 million cases are symptomatic and 56,600 people die of hepatitis E-related disease [1]. It is also known as epidemic associated non-A, non-B (ENANB) hepatitis or enterically transmitted NANB hepatitis as it is transmitted by faeco-oral route and it is distinct from the hepatitis A (HAV) and hepatitis B virus (HBV). The existence of Hepatitis $\mathrm{E}$ virus (HEV) came to notice during the retrospective analysis of the large scale outbreak in Delhi in the year 1955-56 affecting around 29,300 people [2]. Similar studies for the existence of non-A non-B hepatitis virus were reported from Kashmir valley and different parts of India [3,4]. In 1983, Balayan and co-worker's demonstrated the viral particle by immune electron microscopy in faecal sample of the research team workers who themselves ingested the pooled faecal extract of the patients with non A non B hepatitis [5]. Since then many such outbreaks from different geographical regions have been reported, mainly from developing countries where general sanitation and hygiene conditions are poor and safe drinking water is not available adequately. However, even in developed countries, HEV has been known to cause outbreak and sporadic cases due to zoonotic transmission especially from swine [6].

$\mathrm{HEV}$ is a non-enveloped, spherical virus particle with $32-34 \mathrm{~nm}$ size with icosahedral symmetry. Due to its morphological similarity with Norwalk virus it was placed under Calciviruses [5]. However with the use of cryo-electron microscopy and crystallography, the structure of HEV was well defined. The International committee for Taxonomy of viruses (ICTV) has now placed the virus under the family Hepeviridae and genus Hepevirus [7]. HEV has a positive sense single stranded RNA of $7.2 \mathrm{~kb}$ in length. The viral genome consists of a short 5 ' terminal capped end with three open reading frames (ORF 1-3) and a 3' end with adenosine stretch (Figure 1) [8]. The ORF 1 codes for the viral non-structural proteins which have a role in capping of viral genome and viral replication. The ORF 2 encodes for the capsid protein, which is an important antigenic component of the virus and ORF 3 codes for the proteins that have an important role in the genetic assembly and virion release [9]. The virus is resistant to acid, bile acids and heating at $56^{\circ} \mathrm{C}$ for $1 \mathrm{hr}$.

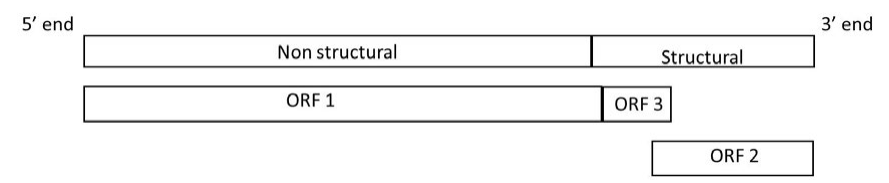

Figure 1. Genomic organization of hepatitis E virus (HEV) showing the open reading frames (ORF). Adapted from Adapted from Pérez-Gracia MT et al. [8].
HEV has four genotypes and single serotype. Each genotype differs from each other by $25 \%$ or more and has its own geographical distribution and host susceptibilities [10,11]. Genotype 1 and 2 are known to infect human and non-human primates and are found in developing countries like Asia, Africa and Latina America and are predominately transmitted by faeco oral route [10]. On the other hand, genotype 3 and 4 are predominantly acquired by zoonotic route especially from the intake of contaminated food and have been recovered from swine, deer, rabbits, rats, cattle and others apart from humans $[6,10,12]$.

The HEV infection is acquired by oral route from contaminated water or food [13]. However there are reports of transmission by body fluids of infected animals, infected blood products and mother to child transmission $[14,15]$. Following the entry of virus in the gut, the virus reaches the liver via portal vein. Of the several receptors recognized, heparan sulphate proteoglycans serves as the low affinity receptor promoting the virus contact with the hepatocytes [16]. HEV replicates in the protoplasm of the hepatocytes and later is released in the blood and bile, leading to viraemia and faecal shedding of virus [17].

Incubation period of $\mathrm{HEV}$ infection ranges from 2 weeks to 2 months. The clinical symptoms and signs of HEV cannot be differentiated from the other cases of hepatitis [10,18]. The usual clinical features include fever, malaise, vomiting, jaundice, headache and abdominal pain. The individual affected are usually young adults in genotype 1 and 2 infections, whereas the older age groups and immunosuppressed patients are affected in case of infection caused by genotype 3 and 4 . The males are more affected than females $[7,18]$. The disease is known to progress more severely in patients infected with both human and swine strain of HEV especially in patients of poor countries [19]. The disease usually presents in any of the three forms. The acute viral hepatitis with a self-limiting course, acute liver failure especially in case of pregnant women and patients with existing liver disease. Recently, chronic HEV infection has also been documented transplant recipients and in some patients on chemotherapy and Human immunodeficiency virus (HIV) co-infection [19]. Chronic hepatitis is usually associated in case of infection caused by HEV genotype 3 . The pregnant women are known to develop acute liver failure due to high viral load and hormonal abnormalities in pregnancy [20]. The severity of infection in pregnancy increases with each passing

Correspondence to: Dr. Mini P Singh, Additional Professor, Department of Virology, Postgraduate Institute of Medical Education and Research, Chandigarh, India, Tel: 0091-0172-2755170; Fax: 0091-0172-2744401; E-mail: minipsingh@gmail.com

Received: May 20, 2016; Accepted: June 20, 2016; Published: June 24, 2016 
trimester. The risk of foetal loss in high in first trimester of pregnancy. The overall mortality in HEV infection is around $1 \%$ in immunecompetent patients, $20 \%$ in pregnancy and around $30 \%$ in patients with chronic liver disease $[21,22]$. HEV can also present with subclinical infections with low viral load in case of outbreak settings and endemic areas. These subclinical infections serve as the reservoir of HEV in the local community [23].

The diagnosis of HEV infection can be made in early phase of infection by HEV RNA detection in stool and serum samples [24]. The viraemia and faecal shedding usually starts 3 weeks after infection and 1 week prior to the diseases onset. The viraemia diminishes with time even though the faecal shedding may persist for days to weeks [11]. HEV RNA detection targeting the conserved region between HEV genotype is useful in especially in the early phase, in patients with immunosuppression who may not mount an antibody response. Viral load determination may be important in cases of chronic infections caused by HEV to determine the response to treatment [25]. Recently, HEV antigen detection has also been found to be an early diagnostic marker especially in the first 3 days of infection when patient may not have detectable anti-HEV antibodies [26]. This has a distinct advantage over HEV RNA detection that it can be done in a routine serology laboratory. The routine diagnosis of current HEV infection rests on the detection of IgM anti-HEV antibodies by ELISA which usually becomes detectable by the end of first week of disease onset and may last up to 5 months $[27,28]$. The IgG anti- HEV antibodies peak 2-4 weeks after onset of disease, and is known to persist for years in low levels [11]. In case of outbreak settings, the use of dried blood spots (DBS) samples for detection anti-HEV IgM antibodies has also been shown to be useful [29]. Most of the acute HEV infections resolve on their own and may need occasional symptomatic treatment. Antiviral therapy like ribavirin and interferon are used in cases of chronic infections. In recent studies, sofosbuvir has been found to be effective in inhibiting HEV replication and can be used as an adjunctive to ribavirin therapy for chronic hepatitis E infections [30].

\section{Hepatitis E vaccine}

Though, both HAV and HEV share common characteristic of enteric transmission by faeco-oral route, but both are quite different in their biological properties. There is successful vaccine available against HAV, but no such vaccine is still available against HEV. However, there is a hope to develop successful vaccine against HEV as only single serotype is present and passive immunization with high titre anti-HEV plasma or serum has been shown to provide protection against different genotypes in non-human primates when challenged with HEV [31].

\section{Need for vaccine}

HEV infection is a disease of global concern with one-third of the world's population being infected. The prevalence reported is just the tip of an iceberg, where the actual load of the disease is under reported. $\mathrm{HEV}$ is capable of causing outbreaks and epidemics. There is possibility of reinfection in the communities where HEV is known to be endemic and in patients with altered immune response [18].

\section{Target groups}

The HEV vaccine may be beneficial in pregnant females and in patients with pre-existing chronic liver disease who are prone to develop acute liver failure. Also, there may be some role of the vaccine in transplant recipients who are predisposed to develop chronic liver disease.

\section{Vaccine designing}

Among the several HEV viral proteins, the ORF 1 and ORF 3 encoded proteins are less accessible to antibodies and don't completely neutralize the virus $[32,33]$. The ORF2 encoded viral capsid proteins have been shown to be highly conserved, have better neutralizing ability, generate long lived antibodies and have shown high cross reactivity with different HEV genotypes and hence are better candidates for vaccine development [34].

Due to the difficulty in growing HEV in cell lines, the antigen targets are prepared by recombinant technology [35]. Two systems, Escherichia coli and insect cells from baculovirus vectors have been effective to express the HEV viral proteins. The protein forms expressed are usually the truncated proteins as the full-length proteins are relatively hydrophobic and insoluble. Till date two vaccines have been studied extensively, there are Escherichia coli derived vaccines and Baculovirus expressed vaccines.

\section{Escherichia coli derived vaccine}

The E. coli derived viral proteins of $23 \mathrm{kDa}$ (aa 394-606) and $30 \mathrm{kDa}$ (aa 368-606) prepared by the Wantai Biological pharmaceutical Co in China have been studied in trials [36]. Initially, the preclinical trial studies were done in rhesus monkeys which were given two vaccine doses at an interval of 4 weeks. The infection challenge was given in two sets (high-dose and low-dose), and samples were taken 3 weeks after the $2^{\text {nd }}$ dose. The protective efficacy was observed to be $75 \%$ and $100 \%$ in high dose and low dose challenged monkeys respectively. The vaccine also showed cross protection to genotype 4 in addition to genotype 1 [36].

In China, HEV 239 E. coli vaccine was given to 612 seronegative subjects. The seroconversion was reported to be $100 \%$ when 3 doses of $10 \mu \mathrm{g}$ were given and $98 \%$ when 2 doses of $20 \mu \mathrm{g}$ were given. With good safety and efficacy, this vaccine entered into Phase 3 trial [37]. The Phase 3 trial was carried out in China under the sponsorship of Ziamen Innovax Biotech. A total of 112604 healthy male and female individuals were divided into vaccine and placebo groups [38]. Three doses of 30 $\mu \mathrm{g}$ were given intramuscularly to adults (16-65 years) and active HEV infection was followed up till 13 month after vaccination. The efficacy was found to be $100 \%$ (CI 9.1\%-100\%) after the second dose and $100 \%$ (CI, 72.1\%-100\%) after the third dose. The vaccine had few mild side effects [38]. This vaccine with the name "HEV 239" or Hecolin ${ }^{\circ}$ Innovax is licensed in China for use in patients of age group 16-65 yrs who are prone to HEV infection like pregnant women, traveller to endemic countries, military recruits and animal food handlers [38]. The vaccine efficacy has been found to be good in patients aged 16-65 years for genotype 1 and 4; however its efficacy in genotype 2 and 3 and in extreme age groups needs to be clearly evaluated [39].

\section{Baculovirus derived vaccine}

The Baculovirus expressed genotype 1 viral proteins of $62 \mathrm{kDa}$; $56 \mathrm{kDa}$ and $53 \mathrm{kDa}$ were initially evaluated in in-vitro and in-vivo experiments. The $56 \mathrm{kDa}$ (aa112-278) protein showed better results and was prepared by GlaxoSmithKline (GSK), Belgium for trial studies [40]. In the preclinical trial, two different formulations with different vaccination dose schedules were evaluated in rhesus monkeys [41]. Following the vaccination, the monkeys were subjected to challenge by one of the three genotype viruses (genotype 1,2 and 3 strains). The protective efficacies were noted to be $100 \%$ and $75 \%$ in two dose and single dose regimen groups respectively. The vaccine provided 
protection against all genotypes. The placebo group developed hepatitis in $75 \%$ of the cases [41].

The phase I clinical trial of Baculovirus vaccine was carried out by Walter Reed Army Institute of Research in US army volunteers. The individuals with age of 18-50 years were administered 3 doses of four $(1,5,20,40 \mu \mathrm{g})$ formulations. The seroconversion rates were $89 \%$ to $95 \%$ in higher dose formulations [42]. The phase II trial was carried out in Nepal army volunteers where HEV infection is endemic [43]. A total of 1794 healthy young adults, mostly male individuals were evaluated for the efficacy in vaccine and placebo groups. A total of 3 doses each of $20 \mu \mathrm{g}$ strength were given at $0,1,6$ months intramuscularly and followed up for clinical infection till 2 years after vaccination. The seroconversion rate at 1 month after $3^{\text {rd }}$ dose was $100 \%$. The vaccine efficacy was found to be $95.5 \%$ (CI, 85.6\%- 98.6\%) and $85.7 \%(\mathrm{Cl}, 16 \%$ 98.2\%) in individuals who received 3 doses and 2 doses respectively. This vaccine has been found to be effective in regions where HEV is endemic [43].

The need of the hour is that these vaccines should be introduced in to the market and made available at reasonably low price to the community [44]. Till date, both the vaccines have been found to be effective in different setups and have been extensively reviewed by the e Global Advisory Committee on Vaccine Safety (GACVS) [39]. The HEV 239 vaccine was considered to be better vaccine based on the phase III trials, however the data on safety in patients with pre-existing liver disease, in patients $<16$ year and $>65$ years and cross protection for genotype 2 and 3 is lacking. Due to insufficient information about safety and efficacy of this vaccine, WHO does not recommend it for the routine use in the national immunization programmes. However, it recommends the use HEV 239 vaccine in outbreak settings and pregnant women, where the risk of complications and mortality is higher. However the use of HEV 239 vaccine in case of travellers and outbreak associated health care and relief workers needs to be decided on the basis of cost - benefit ratio [39]. WHO in view of the global burden of HEV, has come up with initiatives to fill in the gap in information, so that in the years to come a proper vaccination programme is available.

\section{References}

1. WHO (2016) Hepatitis E [Internet].

2. Viswanathan R (2013) Infectious hepatitis in Delhi (1955-56): a critical studyepidemiology. 1957. Natl Med J India 26: 362-377. [Crossref]

3. Khuroo MS (1980) Study of an epidemic of non-A, non-B hepatitis. Possibility of another human hepatitis virus distinct from post-transfusion non-A, non-B type. Am J Med 68: 818-824. [Crossref]

4. Wong DC, Purcell RH, Sreenivasan MA, Prasad SR, Pavri KM (1980) Epidemic and endemic hepatitis in India: evidence for a non-A, non-B hepatitis virus aetiology. Lancet 2: 876-879. [Crossref]

5. Balayan MS, Andjaparidze AG, Savinskaya SS, Ketiladze ES, Braginsky DM, et al. (1983) Evidence for a virus in non-A, non-B hepatitis transmitted via the fecal-oral route. Intervirology 20: 23-31. [Crossref]

6. Meng XJ (2010) Hepatitis E virus: animal reservoirs and zoonotic risk. Vet Microbiol 140: 256-265. [Crossref]

7. Emerson SU, Anderson D, Arankalle A, et al (2004) Virus taxonomy: VIIIth report of the International Committee on Taxonomy of Viruses. Elsevier/Academic Press, London 979-996.

8. Pérez-Gracia MT, García M, Suay B, Mateos-Lindemann ML (2015) Current Knowledge on Hepatitis E. J Clin Transl Hepatol 3: 117-126. [Crossref]

9. Emerson SU, Nguyen HT, Torian U, Burke D, Engle R, Purcell RH (2010) Release of genotype 1 hepatitis $\mathrm{E}$ virus from cultured hepatoma and polarized intestinal cells depends on open reading frame 3 protein and requires an intact PXXP motif. $J$ Virol 84: 9059-9069. [Crossref]

10. Purcell RH, Emerson SU (2008) Hepatitis E: an emerging awareness of an old disease $J$ Hepatol 48: 494-503. [Crossref]

11. Fields BN, Knipe DM, Howley PM (2013) Fields virology. 6th ed. Philadelphia: Wolters Kluwer Health/Lippincott Williams \& Wilkins 2246-2247.

12. Takahashi K, Kitajima N, Abe N, Mishiro S (2004) Complete or near-complete nucleotide sequences of hepatitis $\mathrm{E}$ virus genome recovered from a wild boar, a deer, and four patients who ate the deer. Virology 330: 501-505. [Crossref]

13. Purcell RH, Emerson SU (2010) Hidden danger: the raw facts about hepatitis E virus. $J$ Infect Dis 202: 819-821. [Crossref]

14. Meng XJ, Wiseman B, Elvinger F, Guenette DK, Toth TE, et al. (2002) Prevalence of antibodies to hepatitis $\mathrm{E}$ virus in veterinarians working with swine and in normal blood donors in the United States and other countries. J Clin Microbiol 40: 117-122. [Crossref]

15. Arankalle VA, Chobe LP (2000) Retrospective analysis of blood transfusion recipients: evidence for post-transfusion hepatitis E. Vox Sang 79: 72-74. [Crossref]

16. Kalia M, Chandra V, Rahman SA, Sehgal D, Jameel S (2009) Heparan sulfate proteoglycans are required for cellular binding of the hepatitis E virus ORF2 capsid protein and for viral infection. J Virol 83: 12714-12724. [Crossref]

17. Chauhan A, Jameel S, Dilawari JB, Chawla YK, Kaur U, et al. (1993) Hepatitis E virus transmission to a volunteer. Lancet 341: 149-150. [Crossref]

18. Khuroo MS, Khuroo MS (2016) Hepatitis E: an emerging global disease - from discovery towards control and cure. J Viral Hepat 23: 68-79. [Crossref]

19. Kamar N, Dalton HR, Abravanel F, Izopet J (2014) Hepatitis E virus infection. Clin Microbiol Rev 27: 116-138. [Crossref]

20. Bose PD, Das BC, Kumar A, Gondal R, Kumar D, et al. (2011) High viral load and deregulation of the progesterone receptor signaling pathway: association with hepatitis E-related poor pregnancy outcome. J Hepatol 54: 1107-1113. [Crossref]

21. Jilani N, Das BC, Husain SA, Baweja UK, Chattopadhya D, et al. (2007) Hepatitis E virus infection and fulminant hepatic failure during pregnancy. $J$ Gastroenterol Hepatol 22: 676-682. [Crossref]

22. Kc S, Sharma D, Basnet BK, Mishra AK (2009) Effect of acute hepatitis E infection in patients with liver cirrhosis. JNMA J Nepal Med Assoc 48: 226-229. [Crossref]

23. Majumdar M, Singh MP, Goyal K, Chawla Y, Ratho RK (2015) Detailed investigation of ongoing subclinical hepatitis E virus infections; occurring in outbreak settings of North India. Liver Int 35: 826-833. [Crossref]

24. Mirazo S, Ramos N, Mainardi V, Gerona S, Arbiza J (2014) Transmission, diagnosis, and management of hepatitis E: an update. Hepat Med 6: 45-59. [Crossref]

25. Mikolašević I, Sladoje-Martinović B, Orlić L, Milić S, Lukenda V, et al. (2014) [Evaluation of viral hepatitis in solid organ transplantation]. Acta Med Croatica 68 151-159. [Crossref]

26. Majumdar M, Singh MP, Pujhari SK, Bhatia D, Chawla Y, et al. (2013) Hepatitis E virus antigen detection as an early diagnostic marker: report from India. $J$ Med Virol 85: 823-827. [Crossref]

27. Bryan JP, Tsarev SA, Iqbal M, Ticehurst J, Emerson S, et al. (1994) Epidemic hepatitis $\mathrm{E}$ in Pakistan: patterns of serologic response and evidence that antibody to hepatitis $\mathrm{E}$ virus protects against disease. J Infect Dis 170: 517-521. [Crossref]

28. Dawson GJ, Chau KH, Cabal CM, Yarbough PO, Reyes GR, Mushahwar IK (1992) Solid-phase enzyme-linked immunosorbent assay for hepatitis E virus IgG and IgM antibodies utilizing recombinant antigens and synthetic peptides. $J$ Virol Methods. 38: 175-186. [Crossref]

29. Singh MP, Majumdar M, Budhathoki B, Goyal K, Chawla Y, et al. (2014) Assessment of dried blood samples as an alternative less invasive method for detection of Hepatitis E virus marker in an outbreak setting. J Med Virol 86: 713-719. [Crossref]

30. Dao Thi VL, Debing Y, Wu X, Rice CM, Neyts J, et al. (2016) Sofosbuvir Inhibits Hepatitis E Virus Replication In Vitro and Results in an Additive Effect When Combined With Ribavirin. Gastroenterology 150: 82-85. [Crossref]

31. Pillot J, Türkoglu S, Dubreuil P, Cosson A, Lemaigre G, Meng J, et al. (1995) Crossreactive immunity against different strains of the hepatitis $\mathrm{E}$ virus transferable by simian and human sera. Comptes Rendus Académie Sci Sér III Sci Vie. 318: 1059-1064. [Crossref] 
32. Zhou Y-H, Purcell RH, Emerson SU (2005) A truncated ORF2 protein contains the most immunogenic site on ORF2: antibody responses to non-vaccine sequences following challenge of vaccinated and non-vaccinated macaques with hepatitis $E$ virus. Vaccine. 23: 3157-3165. [Crossref]

33. Ma H, Song X, Harrison TJ, Li R, Huang G, Zhang H, et al. (2009) Immunogenicity and efficacy of a bacterially expressed HEV ORF3 peptide, assessed by experimental infection of primates. Arch Virol. 154: 1641-1648. [Crossref]

34. Emerson SU, Clemente-Casares P, Moiduddin N, Arankalle VA, Torian U, Purcell RH (2006) Putative neutralization epitopes and broad cross-genotype neutralization of Hepatitis E virus confirmed by a quantitative cell-culture assay. J Gen Virol. 87: 697-704. [Crossref]

35. Im SW, Zhang JZ, Zhuang H, Che XY, Zhu WF, Xu GM, et al. (2001) A bacterially expressed peptide prevents experimental infection of primates by the hepatitis $\mathrm{E}$ virus. Vaccine. 19: 3726-3732. [Crossref]

36. Li SW, Zhang J, Li YM, Ou SH, Huang GY, He ZQ, et al. (2005) A bacterially expressed particulate hepatitis $\mathrm{E}$ vaccine: antigenicity, immunogenicity and protectivity on primates. Vaccine. 23: 2893-2901. [Crossref]

37. Zhang J, Liu CB, Li RC, Li YM, Zheng YJ, Li YP, et al. (2009) Randomized-controlled phase II clinical trial of a bacterially expressed recombinant hepatitis $\mathrm{E}$ vaccine. Vaccine. 27: 1869-1874. [Crossref]
38. Zhu FC, Zhang J, Zhang XF, Zhou C, Wang ZZ, Huang SJ, et al. (2010) Efficacy and safety of a recombinant hepatitis $\mathrm{E}$ vaccine in healthy adults: a large-scale, randomised, double-blind placebo-controlled, phase 3 trial. Lancet. 376: 895-902. [Crossref]

39. [No authors listed] (2015) Hepatitis E vaccine: WHO position paper, May 2015. Wkly Epidemiol Rec 90: 185-200. [Crossref]

40. Robinson RA, Burgess WH, Emerson SU, Leibowitz RS, Sosnovtseva SA, Tsarev S, et al. (1998) Structural characterization of recombinant hepatitis E virus ORF2 proteins in baculovirus-infected insect cells. Protein Expr Purif. 12: 75-84. [Crossref]

41. Purcell RH, Nguyen H, Shapiro M, Engle RE, Govindarajan S, et al. (2003) Pre-clinical immunogenicity and efficacy trial of a recombinant hepatitis E vaccine. Vaccine 21: 2607-2615. [Crossref]

42. Safary A (2001) Perspectives of vaccination against hepatitis E. Intervirology 44: 162 166. [Crossref]

43. Shrestha MP, Scott RM, Joshi DM, Mammen MP Jr, Thapa GB, et al. (2007) Safety and efficacy of a recombinant hepatitis E vaccine. $N$ Engl J Med 356: 895-903. [Crossref]

44. Ferguson M, Walker D, Mast E, Fields H (2002) Report of a collaborative study to assess the suitability of a reference reagent for antibodies to hepatitis $\mathrm{E}$ virus. Biologicals 30: 43-48. [Crossref]

Copyright: (2016 Zaman K. This is an open-access article distributed under the terms of the Creative Commons Attribution License, which permits unrestricted use, distribution, and reproduction in any medium, provided the original author and source are credited. 